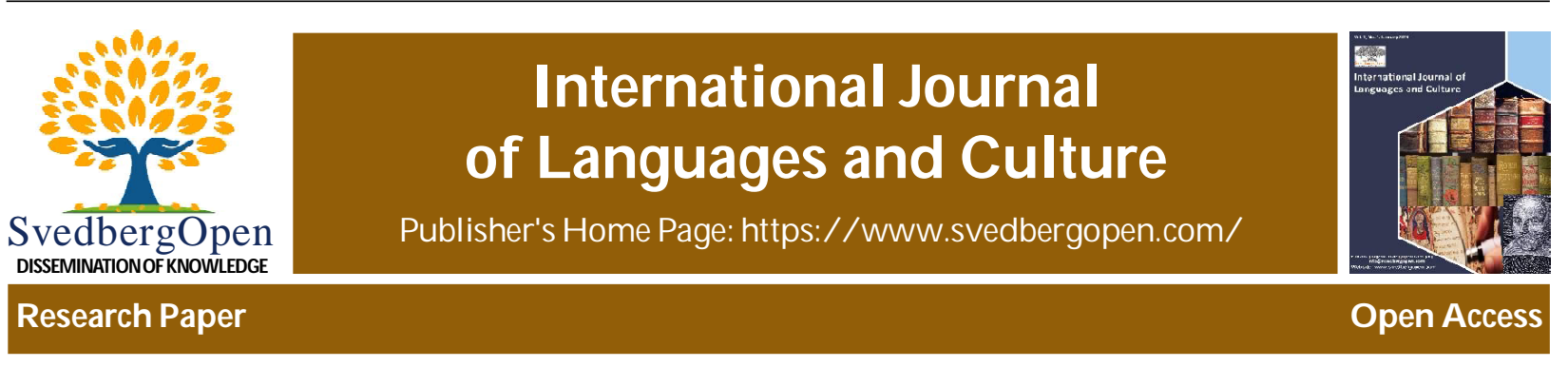

\title{
Notes of another native son
}

Mwatabu S. Okantah ${ }^{1^{*}}$

${ }^{1}$ Associate Professor, Department of Pan-African Studies, Kent State University, United States. E-mail: mokantah@kent.edu

\section{Article Info}

Volume 1, Issue 1, March 2021

Received : 11 November 2020

Accepted : 28 January 2021

Published : 05 March 2021

doi: 10.51483/IJLC.1.1.2021.9-17

\section{Abstract}

Like Baldwin, I, too, am “A Stranger in the Village.” This realization would not come while visiting some remote European village. Baldwin's collection of essays, Notes of a Native Son, helped me recognize I am a stranger in the country where I was born. I live in a peculiar kind of exile here in the land of my birth. I am no more than a familiar stranger living in this land my passport says is my country of origin. The election of America's first black President notwithstanding, and more than two decades removed from the Civil Rights era, African Americans are no more or less visible in the United States today than we were when Ralph Ellison wrote his classic novel, Invisible Man. Things have changed, yet too much has remained the same. We are still a people in search of a proper name. We are a people trying to find a secure place in this land where I rarely, if ever, feel at home. My travels through West Africa would bring this stark reality into sharper focus. The search for a healthy black identity remains a most daunting challenge and coming to terms with our African heritage is still at the center of that inner conflict.

Keywords: Baldwin's collection, European village, Native son, Stranger, African heritage

(C) 2021 International Journal of Languages and Culture. This is an open access article under the CC BY license (https://creativecommons.org/licenses/by/4.0/), which permits unrestricted use, distribution, and reproduction in any medium, provided you give appropriate credit to the original author(s) and the source, provide a link to the Creative Commons license, and indicate if changes were made.

\section{Introduction}

The View from Stono: Reflections, Reminiscences and Ruminations is essentially a memoir that combines my research, commentary and creative non-fiction. This work speaks to my personal, philosophical and my aesthetic development over the course of my career. I have come to know myself as a poet/performing artist—a Griot—disguised as a college professor. More importantly, I found myself as a black man when I discovered myself as a poet. Poetry opened a virtual window into my inner Self. The poetry I discovered hidden deep inside gave voice to feelings, thoughts and emotions I could feel as well as a powerful mode of expression to wield as a weapon in the war to liberate the minds of a people held hostage for so long, we have forgotten the true meaning of being free.

The View from Stono is the logical extension of my poetry beyond the limits of "the poem" as a form of communication. Stono satisfies the urge to say things in ways I cannot necessarily convey in poetry or in song lyrics yet need to share with the same intensity and poet/singer's sensibility.

I am Guerrilla Dread,

forever

the Poet/

Griot

\footnotetext{
* Corresponding author: Mwatabu S. Okantah, Associate Professor, Department of Pan-African Studies, Kent State University.
}

E-mail: mokantah@kent.edu; www.mkepoet1.com 
speaking/singing/

seeing/

remembering/story-

telling/

being in the moment and capturing those moments in lyrical word-time.

The title comes from a former mentor and Supervisor, when I served as Assistant to the Director of Black Studies at Cleveland State University. Curtis Wilson was Alabama bred and Brer Rabbit wise. He made me realize the importance of going into the American Black Belt South before going home to West Africa. He suggested that I begin my pilgrimage to ancestral lands at the site of the 1739 Stono slave insurrection in the South Carolina low country just south of Charleston. It was during those years with Professor Wilson when I became convinced the questions of cultural definition and identity posed the crucial conundrum of our time.

Reading Barack Obama's (1995) poignant, Dreams from My Father, there was a tone that struck a personal chord. His story moved me to reread James Baldwin's probing essay, "A Stranger in the Village," from his classic, Notes of a Native Son. "Notes of Another Native Son" is the final offering in The View from Stono. It is an exploration of the common themes and questions about black identity I see running from Baldwin writing in the middle of the $20^{\text {th }}$ century to Barack Obama claiming a sense of his own cultural heritage as an African American at the close of that century to my own quest to define myself as an American-born African in these still turbulent and troubled times, 20 years into this new millennium.

\section{"Notes of another Native Son"}

What one's imagination makes of other people is dictated, of course, by the laws of one's own personality and it is one of the ironies of black-white relations that, by means of what the white man imagines the black man to be, the black man is enabled to know who the white man is. ${ }^{1}$

—James Baldwin

\section{The Context}

Like Baldwin, I, too, am "A Stranger in the Village." However, this realization would not come while visiting some remote European village. Baldwin's collection of essays, Notes of a Native Son, helped me recognize I am a stranger in the village where I was born. I live in a peculiar kind of exile here in the land of my birth. I am no more than a familiar stranger living in this land my passport says is my country of origin. Two terms of America's first black President notwithstanding, and more than two decades removed from the Civil Rights era, African Americans are no more or less visible today than we were when Ralph Ellison wrote his classic novel, Invisible Man. Things have changed, yet too much has remained the same. We remain a people in search of a proper name while still trying to find safe space in this land where I rarely, if ever, feel at home.

My travels through West Africa always bring this stark reality into sharper focus. The search for a healthy black identity remains a most daunting challenge and coming to terms with our African heritage is still at the center of that internal turmoil. Like Barack Obama in his book, Dreams from My Father: A Story of Race and Inheritance, being in Africa would enable me to merge my two warring Selves into one. He writes, "Africa had become an idea more than an actual place, a new promised land.... With the benefit of distance, we engaged Africa in a selective embrace - the same sort of embrace I'd once offered the Old Man. What would happen once I relinquished that distance? It was nice to believe that the truth would somehow set me free. But what if that was wrong? What if the truth only disappointed...?"2 My experiences have taught, the truth can only disappoint to the degree we attempt to ignore or deny it. The reality of Africa forced me to look into the mirror to confront my African American truth.

Baldwin, as essayist and social critic, made it easier to probe deeper inside my own sense of uncharted American space. He writes:

The idea of white supremacy rests simply on the fact that white men are the creators of civilization ... and are therefore civilization's guardians and defenders. Thus, it was impossible for Americans to accept the black man as one of themselves, for to do so was to jeopardize their status as white men. But not so to accept him was to deny his human reality ... and the strain of denying the overwhelmingly undeniable forced Americans into rationalizations so fantastic that they approached the pathological. ${ }^{3}$

\footnotetext{
James Baldwin, "Stranger in the Village," Notes of a Native Son. Boston: Beacon Press, 1955, Pg. 167.

Barack Obama, Dreams from My Father: A Story of Race and Inheritance. New York, Three Rivers Press, 1995, Pg. 302.

Baldwin, Pg. 172.
} 
There can be no real understanding of the true nature of this society if we do not consider it from the point of view of those people who created it-the real "native Americans." America was born a settler nation constructed as an extension of England in particular and Europe in general. Chattel slavery provided the economic foundation that made its material development possible. Descended from enslaved Africans in the wilderness, who can know this society more intimately than those of us who have been locked out of its promise? Put another way, who can know the white man better than those of us who have desperately_ and sometimes foolishly_tried to remake ourselves into one?

I often wonder if there is anything new to be said or discussed about race relations in this country. It seems we are already inexorably trapped in a most uncomfortable middle ground, a virtual mine field of conflicting thoughts and emotions. "Black and white" is always the issue lurking just below the surface of an uneasy calm. In Two Nations: Black and White, Separate, Hostile, Unequal, Hacker (1992) argues, "Race has been an American obsession since the first European sighted 'savages' on these shores. In time, those original inhabitants would be subdued or slaughtered, and finally sequestered out of view. But race in America took on a deeper and more disturbing meaning with the importation of Africans as slaves... That Americans of African origin once wore the chains of chattels remains alive in the memory of both races and continues to separate them."4

Hacker's work is a must read if one truly wishes to understand the socio-cultural, as well as the historical ramifications of race relations in the United States. He contends, "[the] Europeans who colonized the western hemisphere sought to recreate it in their image, and to transform North and South America into 'white' continents. With conquest comes the power to impose your ways on territories you have subdued." ${ }^{5} \mathrm{He}$ adds, "From the colonial period through the Jacksonian era, most white Americans were of English ancestry....the Anglo-American model has remained remarkably durable, with most subsequent immigrants adapting to its cannons. They not only learned English, the single national language, but also adjusted their lives to the economy and technology associated with that prototype.... It could be argued that most contemporary citizens associate themselves to a greater degree with Anglo-American culture than their actual country of origin." 6

I am always astonished at just how little the average American knows about the making of America. It is the peculiar dynamic of the black presence in this society that has compelled many people to reconsider time-honored American rhetoric. When I ask my students or, people in general, to identify the dominant European ethnic group in the shaping of American society, I am usually greeted with blank stares. After some thought, black students will answer, "white people." For my white students, the question makes no sense. No one seems to have thought about who stirs the melting pot. The true "native" Americans are the only group that did not have to experience being melted down in the pot. The people who discovered the English at Jamestown, and later, at Plymouth Rock, were not lost. They knew their world was old. There was no vision called "America" in their reality. They had no way of knowing the people they rescued and helped nurture back to health would one day turn on them, then rename and annihilate them.

Hacker adds this insight, "America has always been the most competitive of societies. It poises its citizens against one another, with the warning that they must make it on their own. Hence the stress on moving past others, driven by a fear of falling behind. No other nation so rates its residents as winners or losers. If white America orchestrates this arena, it cannot guarantee full security to every member of its own race. Still, while some of its members may fail, there is a limit to how far they can fall. For white America has agreed to provide a consolation prize: no matter to what depths one descends, no white person can ever become black. As James Baldwin has pointed out, white people need the presence of black people as a reminder of what providence has spared them from becoming."

Most white Americans would probably consider Hacker's views extreme and divisive. At the same time, those same Americans would deny or dismiss the white supremacist mindset of this society's founders. Few ever ponder the real psychology, the privileges or the mythology of whiteness. These same Americans would think it inconceivable that people they regard as "others" would dare question the legitimacy of their perceptions of basic American reality. They are unable to acknowledge that we do exist in separate realities. We can look at the same thing and see different things. It did not take the O. J. Simpson murder trial, the humanitarian debacle of hurricane Katrina or the horrific deaths of George Floyd and Breonna Taylor to confirm this fact of American life. We live in separate worlds and the question of why haunts this nation.

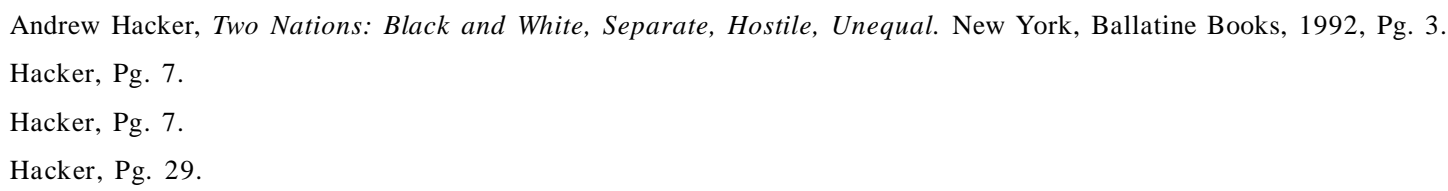


This specter of race renders even the most innocent encounters potentially dangerous. When Europeans made the calculated business decision to systematically kidnap African people for sale into slavery in the New World, they quite unwittingly set historical forces in motion even they, in their wildest dreams, could not have imagined. The Founding Fathers should have heeded Franklin (1751). In his “Observations Concerning the Increase of Mankind," he ruminated, "And while we are ... scouring our planet, by clearing America of woods, and so making this side of our globe reflect a brighter light ... why should we darken its people? Why increase the Sons of Africa, by planting them in America, where we have so fair an opportunity, by excluding all blacks and tawneys, of increasing the lovely white and red?" ${ }^{\text {" Who can }}$ deny that black people in this country, and, throughout the world, continue to be seen as nothing more than a series of problems to be debated and eventually solved?

Returning to Baldwin's, “A Stranger in the Village," he argues,"... the American vision of the world—which allows so little reality, generally speaking, for any of the darker forces in human life ... owes a great deal to the battle waged by Americans to maintain between themselves and black men a human separation which could not be bridged.... this vision of the world is dangerously inaccurate, and perfectly useless. For it protects our moral high-mindedness at the terrible expense of weakening our grasp of reality. People who shut their eyes to reality simply invite their own destruction, and anyone who insists on remaining in a state of innocence long after that innocence is dead and turns himself into a monster." "White people have historically viewed themselves in contrast to what they have collectively imagined black people to be or what Toni Morrison, in Playing in the Dark: Whiteness and the Literary Imagination, describes as the "not me."

Skin color has been a primary factor in social advancement in this society ever since the Jacksonian era "Age of the Common Man," when a social system of white preferment was transmuted into the American way of life. The Barack Obama Presidency is stunning precisely because he was the first black leader of "a white man's country." It is the very dogged persistence of a more than two century old dialectic of race, class, gender and sex that keeps America forever on the edge of a vast and dangerous social precipice. Americans still ask, "Just who are to be considered Americans today?" But can old definitions be made to fit contemporary realities? Who are the descendents of those original conquering Europeans today? And the unsettling question pressing in upon African Americans in this time of psychological and spiritual crisis is, "Who have we become?"

The rituals of black and white race relations continue to define people to people interactions in American life. Today's discourse on diversity and multiculturalism will not begin to make sense until these crucial, unresolved racial issues are settled. Hacker argues other racial/ethnic groups find themselves sitting as spectators, while America's black and white antagonists try to work out how or whether we can coexist. He offers this cryptic proviso, “... members of all these 'intermediate' groups have been allowed to put a visible distance between themselves and black Americans.... None of the presumptions of inferiority associated with Africa and slavery are imposed on these other ethnicities. Moreover ... second and subsequent generations of Hispanics and Asians are merging into the 'white' category, partly through intermarriage and also by personal achievement and adaptation." ${ }^{10}$ For black people in America, there is no viable honorary white option.

\section{Lost and Found}

Before the cry of "Black is Beautiful!" during the 1960s, living in the Melting Pot meant becoming as near White AngloSaxon Protestant as possible. When black people openly questioned our own ethnic origins, it inspired others to reexamine the vital relationship between ethnicity and being an American. Anglo-American cultural domination had flourished for more than a century without being seriously challenged. The very nature of the African experience in America contradicts the eloquent terms the Founding Fathers chose to articulate what it means to be an American. The Civil Rights Movement shocked vast numbers of non-English white Americans out of their tightly closed ethnic closets. It made open discussions of discrimination against other European immigrants acceptable. This crucial period also made it possible for non-white, non-European newcomers to claim inclusion in the mythical American Dream as well. The question, "Who and what is an American?" took on deeper, and, in the minds of some conservative keepers of the status quo, more sinister implications.

That America is no longer just a "white man's country" is the real bottom line forcing the present call for a more inclusive, multi-racial, culturally diverse American vision. A raised ethnic consciousness and pride among white Americans,

8 Benjamin Franklin, "Observations Concerning the Increase of Mankind, Peopling of Countries, Etc. (1751)," The Papers of Benjamin Franklin, Labaree, Leonard W., et al., Eds. New Haven: Yale University Press, 1959-1999. 4:225-234.

9 Baldwin, Pg. 174

10 Hacker, Pg. 16 
on the other hand, has not necessarily evolved into a more enlightened racial sensibility. The struggle over the "power to define" is no less intense now than it has ever been. The fight over declaring English America's "official language" is a persistent case in point. Divisions within the larger white community aside, white Americans continue to insist on controlling all interpretations of reality. Rather than change, those in power have opted to modify the language used to describe the same white hegemony. Whether it be integration, multiculturalism or diversity, these concepts only have currency to the degree white people accept them. It is more than evident this clash over the power to name represents an uncomfortable, often unsettling, paradigm shift.

American resistance to new ideas is not new; that social developments in this new millennium will require new ways of thinking is the cause of so much conservative angst. It is this nightmare that imbues the Rush Limbaugh/Tea Party to Donald Trump movement with its power. Hacker also presents this revealing observation, “... there is scant evidence that the majority of white Americans are ready to invest in redistributive programs, let alone give of themselves in more exacting ways.... not only is the taxpaying electorate overwhelmingly white, but it is also middleclass, middle-aged and-increasingly ensconced in insulated suburbs. In short, our time is not one receptive to racial remedies." 11 The MAGA Donald Trump viral white backlash to Barack and Michelle Obama as President and First Lady can best be understood in the setting of this toxic social chemistry.

Peoples of all hues in America are gathering at a serious crossroads as this nation staggers forward into a $21^{\text {st }}$ century it was woefully unprepared to face. There can be no solution to racial strife in this society until Americans of European descent decide to discuss, with each other, the negative impact of racism in their lives. This divide is older than the nation. If we can agree historical racism has had a harmful effect on its victims, then what lethal behavioral pathologies have white Americans developed as a consequence of establishing a white supremacy-based society? Before meaningful racial harmony can be achieved, America must ask, "How did slavery and Jim Crow segregation warp basic American sensibilities?" We are living in a time when the ravaging consequences of white supremacy must become an issue for all Americans to meet head-on.

There can be no true dialogue if it is not open and reciprocal. It must not be hampered by restrictive preconditions. We must all acknowledge there are some difficult and painful obstacles that must be overcome. This means white Americans will have to listen to perspectives about the destructive results of white power and privilege they have never had to consider. They will have to see themselves through the eyes of those who are different; those who are not now and have never really been invisible, save in the minds of Americans who have categorized whole peoples as something "other" or "less than." For black people and other peoples of color, the challenge facing us is no less daunting. We, too, must begin to see ourselves and to see each other in a different light. It will be just as difficult for us to speak with genuine voices and to view our own flaws and virtues with new eyes.

\section{The Challenge}

... the Negro's real relation to the White American.... prohibits, simply, anything as uncomplicated and satisfactory as pure hatred. In order really to hate white people, one has to blot so much out of the mind - and the heart—-that this hatred itself becomes an exhausting and self-destructive pose. But this does not mean, on the other hand, that love comes easily: the white world is too powerful, too complacent, too ready with gratuitous humiliation, and, above all, too ignorant and too innocent for that.... ${ }^{12}$

\section{—James Baldwin}

It has taken a long time to accept and embrace that fact that I am a native son in the same way Baldwin or Barack Obama are native sons. To be a native son in a society that essentially despises you is an ultimate act of defiance. It is an attitude of mind. It is a state of being. In his, The Souls of Black Folk, W. E. B. DuBois eloquently described it as a “double consciousness." For Richard Wright and Baldwin's generation, escape to Europe seemed to only make the feeling grow stronger in its raw intensity. Obama writes, "In 1960, the year that my parents were married, miscegenation was still described as a felony in over half the states in the Union. In many parts of the South, my father could have been strung up from a tree for merely looking at my mother the wrong way; in the most sophisticated of northern cities, the hostile stares, the whispers, might have driven a woman in my mother's predicament into a back-alley abortion- or at the very least to a distant convent that could arrange for adoption." ${ }^{13}$ It seems having a white mother only further complicated questions of blackness.

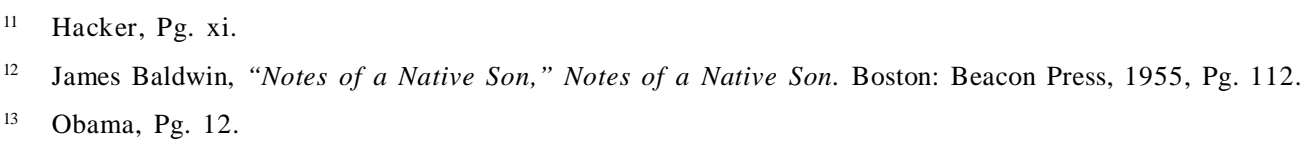


Kenya's Ali Mazrui opens his still penetrating 1986 documentary film series, The Africans: A Triple Heritage, with this lyrical pronouncement, "We are a people of the day before yesterday, and we are a people of the day after tomorrow." I remember a time when I thought African American history began in slavery here in the United States. I was miseducated into accepting the American version of black people's story. As a result, the actual truth appeared lost in some great mystery. Fortunately, by the time I heard Mazrui's words, I had come to understand that although slavery in the Americas marks us as a population, it can never totally define us as a distinct people of African descent. If we are, in fact, a people of the day after tomorrow, we must fashion a new vocabulary to articulate the black experience in the world.

If this nation is to resolve its racial and ethnic tensions, a full range of American voices must be heard. Americans of African descent are just as diverse as any other American cultural group. There is no single way of thinking on any subject. At the same time, I do not apologize because we can claim a shared history and heritage as a distinctly American African people. Those of us who decline to accept an imposed second-class citizenship and who refuse to see ourselves the way America prefers to see black people are not "wild eyed haters" of white people. Maya Angelou was correct. Bitterness gives nothing back. Hatred is wasted energy. The fact so many in mainstream American society harbor an allconsuming need to cast independent black voices in such language is not our heavy burden to bear. We cannot allow ourselves to be measured by irrational white fears.

Who can argue that we do not live in a society historically dominated by Americans of European descent? How can even the most militant black commentator be accused of saying anything that would further divide an already divided house? The African American experience continues to be shaped by the tyranny of skin color as a prerequisite for inclusion and full citizenship status in an American way of life that has always been maintained by people who identify themselves as white and their surrogates. This is not meant to suggest that all white Americans are the same or that all white people are racist. We understand they are not; but exceptions to the rule are not in question. Despite the tortured disclaimers, the group status of white people as the dominating force in American society is still very much the rule.

How can racial harmony ever be achieved when the legitimacy of such views are rarely, if ever, taken seriously? Intransigence is the chief threat to this nation's future. Even within the black community, frank discussion of the true nature of black life in America is too often muted. We condemn those messengers we choose to ignore or to dispute. We must bear part of the responsibility for our own group psychological, emotional and spiritual paralysis. Like our African ancestors before us, what kind of seeds do we continue to sow such that we continue to reap a harvest of despair, mental enslavement and corporate subjugation? Although the current economic crisis is affecting all sectors of American society, there has never been a time in African American history when the black community has not existed in a state of depression in relation to the larger society.

My travels in this country confirm Baldwin's essay, “A Stranger in the Village.” I am a stranger here. When I was first exposed to Notes of a Native Son in the mid-1970s, the essays were already almost 20 years old. Rereading the material again in 2020 is truly profound. His analysis has withstood the test of time, "It is precisely this black-white experience which may prove of indispensable value to us in the world we face today. This world is white no longer, and it will never be white again." ${ }^{14}$ His words resonate with even greater clarity today. I was intrigued to hear strains of Baldwin echoing in Barack Obama's voice as I read his compelling story. It is also evident much of the opposition to the Obama Presidency, despite the convoluted denials, was fueled by resentment of his proud declaration that his white mother and his Kenyan father did not preclude him from claiming his African American heritage.

We are a people that have survived a pernicious culture war which is perhaps without parallel in the annals of human history. Yet, to debate degrees of horror and brutality is not the point. Karenga (1984, 1990), speaking on the subject of reparations at Cuyahoga Community College in Cleveland, prefaced his 1990 keynote address by paraphrasing from his translation of ancient pyramid texts, Selections from the Husia: Sacred Wisdom of Ancient Egypt, "Bear witness to truth and set the scales of justice in their proper place among those who have no voice." He made it clear that raising the subject of reparations is not just a "black thang." He argued the struggle of Africa and African peoples to reclaim the agency to shape our destiny represents the ultimate in universal values. He proclaimed the African holocaust or Maafa must become a model of human suffering.

At no time do I wish to imply there is consensus around this topic. Furthermore, the absence of agreement should not be used as a ploy to demean the validity of the call for reparations. Slavery in the United States was a crime against humanity and the ongoing oppression of the descendents of enslaved Africans in America is a part of that offense. It is forgotten history that Michigan Congressman John Conyers authored legislation-H. R. 40-which called for the formation of a commission to study the impact of slavery on African American development. He contended, “... the

14 James Baldwin, “Stranger in the Village,” Notes of a Native Son. Boston: Beacon Press, 1955, Pg. 175. 
effects of the institution and of subsequent discrimination by the federal government, various state and local governments, private institutions and certain individuals still linger and continue to mar our society.... It is past time that Congress acknowledges the injustice and inhumanity of slavery." We are US citizens today as a direct result of what can only be described as a criminal act.

Indeed, does the fact of long duration living in the United States, by itself, make African Americans full members of this society? What does it mean to declare citizenship in the face of a nation's repeated failure to safeguard and guarantee rights granted by that status? These are hard questions, but they need to be posed, nonetheless. Beyond platitudes extolling the virtues of patriotism, who in America today_black, white or otherwise_-would deny American citizens the real freedom to question the logic of American Dream aspirations? Neither the annual observance of Martin Luther King, Jr.'s birthday as a national holiday, nor the placing of more black faces in high profile positions can negate the reality that black people in America are still considered no more than aliens in the country we are expected to be proud to call home.

The cost has always been too high. Obama writes, "It wasn't a matter of conscious choice ... just a matter of gravitational pull, the way integration always worked, a one-way street. The minority assimilated into the dominant culture, not the other way around. Only white culture could be ... nonracial, willing to adopt the occasional exotic into its ranks.... And we, the half-breeds and the college-degreed, take a survey of the situation and think to ourselves, why should we get lumped in with the losers if we don't have to? We become only so grateful to lose ourselves in the crowd ... and we're never so outraged as when a cabbie drives past us or the woman in the elevator clutches her purse, not so much because we're bothered by the fact that such indignities are what less fortunate coloreds have to put up with every single day of their lives_-although that's what we tell ourselves_-but because we're wearing a Brooks Brothers suit and speak impeccable English and yet somehow been mistaken for an ordinary nigger."15

To be an American of African descent is to live under siege. From David Walker to Malcolm X, from Ida B. Wells to Queen Mother Moore to Black Lives Matter; the ancestors did not fight in vain. The roll call for this struggle is long. Most of the names and faces are obscure or unknown. The unrelenting efforts may go unnoticed, but the work is hopefilled. History does not repeat itself. History is always in the process of being made. Historical moments will bypass those not paying attention. Knowledge is not power. Knowledge without understanding is useless, or dangerous, or both. Wisdom is the beginning of acquiring the power to proactively shape one's destiny. The significance of race has not declined. What is changing are the ways a growing number of people now choose to respond to stark racial realities.

\section{The Afreeka Inside}

Where did I belong? I knew it was too late to ever truly claim Africa as my home. And if I had come to understand myself as a black American, and was understood as such, that understanding remained unanchored to place. What I needed was a community ... that cut deeper than the common despair that black friends and I shared when reading the latest crime statistics, or the high fives I might exchange on a basketball court. A place where I could put down stakes and test my commitments. ${ }^{16}$

- Barack Obama

Who are we? How did we become who we are? Where are we? How did we come to be here? Where are we going? These are vital questions. The answers, like pieces to an intricate jigsaw puzzle, must be put together through agonizing trial and error. Western civilization transformed African people into scorned outsiders. We are a people in search of a different fate. Unlike Baldwin, Wright and so many others, this quest for personal definition did not take me to Europe. Obama summed up his European odyssey this way, “... by the end of the first week or so, I realized that I'd made a mistake. It wasn't that Europe wasn't beautiful... It just wasn't mine. I felt as if I were living out someone else's romance; the incompleteness of my own history stood between me and the sites I saw like a hard pane of glass.... I had been forced to look inside myself and had found only a great emptiness." ${ }^{17}$ Travel to Europe cannot provide the answers to those nagging questions of identity that still torment so many Americans of African descent.

My search took me to South Carolina, to Georgia and from there back across the Atlantic Ocean through what are no longer Doors of No Return to ancestral West Africa. I wandered into the Confederate south first because I had to find the New World Africa in me, before I traveled across the Atlantic to connect with the reality of the Africa the ancestors left behind. We arrived in Ghana, in Accra, with the sun's rise. A brief three-day stopover in Dakar, Senegal had been enough

\footnotetext{
Obama, Pgs. 99-100.

Obama, Pg. 115.

17 Obama, Pgs. 301-302.
} 
to jolt my sensibilities. Muslim Senegal. The land of Cheikh Anta Diop made the true diversity of Africa and its people real for me. The dawn air was cool. It was the rainy season. The morning mist clung low to the ground. The smells in the air brought back all those things I love most about being in Africa; brought back all those safely hidden away thoughts and emotions in a virtual flood.

I remembered my first visit to Africa and thinking subsequent trips could never be as overwhelming. On my second trip - a pilgrimage I had planned for years-I found the experience no less intense than the first. I realized I could not easily readjust when I returned stateside because I was becoming less willing to make the necessary accommodations. Each visit became so awe-inspiring that my transition back into an American frame of reference grew more difficult and unforgiving. Now, as our tour group checked into the Accra Novotel, I was already experiencing an even stronger vibration on this, my third sojourn. I knew I was feeling the collective energy of the group; several were experiencing Africa for the first time. I also knew I was feeling something more. West Africa forces you to confront feelings, thoughts and emotions we truly do not have English words to express.

Standing in that lobby, looking at those faces, I felt the anguished sounds of the moaning Blues God black artists give voice to in our work. I could hear Duke Ellington's scat-singing Jazz Goddess riffing in my inner ear. I was in Africa once again. I had to remind myself that I was not dreaming. I stood in that space just as wonder-filled and wide-eyed as my first-time fellow travelers. We had been up most of the night, but I felt no need to sleep. I was too stimulated to go to bed. I was too wide-awake. I had not come to Africa to sleep. I would welcome sleep only after the return to America, when I would need my dream body to travel back to the continent; when Africa is reduced to memories, photographs, conversations, daydreams and poetry, when the Africa I discovered deep inside would have to sustain me.

I hit the streets. I love being on African streets experiencing the day or the night in African time. I walked looking for faces. I always begin with the faces. Familiar looking faces. I connect with the faces because they always remind me of faces I already know. I see my mother's face or a friend's face. The faces let me know, we are Africans still. I found myself standing at a busy intersection; people running to catch buses and taxis; people hustling and hawking their wares. I was just another face. I travel to Africa to know it by feel-the rhythms, the sounds, smells, colors, the fluid black motion in African time. In Africa, I am a familiar stranger in ways I find comforting. I can be one in the sea of black faces. I can feel that feeling when no one has to tell me I am home. I stood on that street corner feeling $u s$ in the faces, feeling $u s$ in the comings and goings, feeling $u s$ in the sounds.

I will always remember the young Ghanaian who stopped to ask if I were a Jamaican Rasta? When I said I was African American, he smiled and asked my name. I responded, "Okantah." He looked stunned. He hesitated, then said, "I am Francis." Unable to conceal his embarrassment, we looked into each other's eyes without saying anything for what seemed like an eternity. I had had a similar encounter while visiting with the late Nigerian musician, Fela Anikulapo Kuti. He mused, "dis man come from America with African name.” Now, in Ghana, I was the American with a Ga name speaking to a Ghanaian named Francis. I felt a special sense of belonging I can never really verbalize. I let Francis know he did not have to explain how he had come to have a "white man's name." I asked him if his grandmother still lived in the village, and what did she call him? He gave me another curious look. She called him by his Day name, Kwa. I smiled. He was Thursday born.

During Barack Obama's visit to his father's Kenya, he described comparable feelings: "For the first time in my life, I felt the comfort, the firmness of identity that a name might provide, how it could carry an entire history in other people's memories, so that they might nod and say knowingly, 'Oh, you are so and so's son.' No one here in Kenya would ask how to spell my name or mangle it with an unfamiliar tongue. My name belonged and so I belonged, drawn into a web of relationships, alliances and grudges that I did not yet understand." ${ }^{18}$ In Ghana, people loved my name. No one thought it was strange. They never tired of hearing the story of how I came to have a Ghanaian name. Having an African name connected us in ways that did not need to be explained. It made the people I met reflect on their own names. It was as if my embrace of Africa moved them to reconsider their own self-worth as Africans.

In Africa, the faces taught me, "I am not a Black American!" I am a New World African back home from the "other side." I saw the same look in Francis' eyes that I had seen in the eyes of the 102-year-old Akoli village woman in Nigeria who had asked, "Where was America and how did I get there?" She wanted to know what happened in the "America place," so that I could not speak Igbo. More than the recognition I saw in their eyes, it was the familiarity in the faces that spoke loudest. Old Africa and new Afreeka face to face, seeing each other in real time.

Obama writes, “... a steady procession of black faces passed before your eyes ... faces that made me understand the transformation that [Molefi] Asante and other black Americans claimed to have undergone after their first visit to Africa. For a span of weeks or months, you could experience the freedom that comes from not feeling watched, the freedom of believing that your hair grows as it's supposed to grow and that your rump sways the way a rump is supposed to 
sway.... Here the world was black, and so you were just you; you could discover all those things that were unique to your life without living a lie or committing betrayal." 19

In Africa, I experienced that feeling of being "at home" for the first time. In Nigeria and then in Ghana and in Senegal, people would routinely say, "You can be at home here." I was able to lay the heavy burden down. America is the land of my birth. Indeed, I am a citizen of this great but suffering nation.

Africa is home. I am Africa-descended from people kidnapped from as far north on the west coast as the Senegambia, and all along the coastline as far south as Angola; an area that stretched across Mali, Niger, Chad and as far inland as the Congo rain forest. We come from peoples called Yoruba, Igbo, Hausa, Mandinka, Mende, Fon, Wolof, Ga, Ashanti, Fanti, and Tikar. As I traveled through ancestral lands, I was stunned by the degrees to which we still look like those same peoples. In Senegal, a Wolof man told me I was "light skinned like the Fulani."

An American of African descent, I am not at war with America so much as America is at war with me. America is at war with my Black Self because I reject the identity this society would impose. I had to travel back and forth to Africa to discover the true meaning of being African in America. Standing in the open Door of No Return, in House of Slaves on Senegal's Goree Island, I knew we live in a time when we can return. Deep inside the dungeons at Ghana's Cape Coast and Elmina Castles, I surrendered to the feeling of being descended from the one African in ten who survived the infamous Middle Passage. Like the little boy in the Gwendolyn Brooks poem, "The Life of Lincoln West," in Africa, I was able to determine that I am "the real thing."

Turning to Barack Obama one final time, he writes, "When my tears were finally spent, I felt a calmness wash over me. I felt the circle finally close. I realized that who I was, what I cared about, was no longer just a matter of intellect or obligation, no longer a construct of words. I saw that my life in America-the black life, the white life, the sense of abandonment I'd felt as a boy, the frustration and hope I'd witnessed in Chicago_-all of it was connected with this ... earth an ocean away, connected by more than the accident of a name or the color of my skin. The pain I felt was my father's pain. My questions were my brothers' questions. Their struggle, my birthright."20

\section{Conclusion}

In Africa, I, too, reconnected with family. The Africa of today is connected to the Africa of yesterday. I am connected to the Africa of tomorrow. I found the true measure of what I think Richard Wright, James Baldwin and their generation failed to find. I discovered there is a place where we are not disconnected strangers in the village; a welcoming place that I was told would be strange but felt all too familiar. I discovered that even for us, there is a place where we can feel at home. In Africa, I learned to embrace being an American citizen on my own terms. No longer the same Africans taken out of Africa so many centuries ago, in the white-hot furnace of slavery, we became distinct new peoples of African descent. We are New World Africans. We are Africans, still.

\section{References}

Baldwin, James (1995). Notes of a Native Son. Boston: Beacon Press.

Franklin, Benjamin (1751). Observations Concerning the Increase of Mankind, Peopling of Countries, etc. (1751). The Benjamin Franklin Papers, Labaree, Leonard W., et al., eds. New Haven: Yale University Press, 1959-1999. http:/ /www.ditext.com/franklin/observations.html

Hacker, Andrew (1992). Two Nations: Black and White, Separate, Hostile, Unequal. New York: Ballantine Books.

Karenga, Maulana (1990). First Annual African Holocaust Conference Keynote Address [audio cassette], Cuyahoga Community College, Cleveland.

Karenga, Maulana (1984). The Husia: Sacred Wisdom of Ancient Egypt. Los Angeles: Kawaida Publications.

Mazrui, Ali (1986). The Africans: A Triple Heritage [Documentary]. South Burlington: The Annenberg/ CPB Collection. Obama, Barack (1995). Dreams from My Father: A Story of Race and Inheritance. New York: Three Rivers Press.

19 Obama, Pg. 311.

20 Obama, Pgs. 429-430.

Cite this articleas: M watabu S. Okantah (2021). N otes of another nativeson. Internati onal J ournal of Languages and Culture. 1(1), 9-17. doi:10.51483/ IJLC.1.1.2021.9-17. 